\title{
The Accumulation Effect
}

\author{
The Print Media's Impact on Estonian Elections \\ Between 1999-2003
}

\author{
Raivo Palmaru
}

\begin{abstract}
Although numerous studies over the past 20 years have revealed a clear connection between content analysis statistics and the results of public opinion surveys, the media's "minimal effects" hypothesis still remains the overwhelmingly prevailing view. Among other things, it is not clear which of the two influences the other: Do people's political preferences influence the media or do the media influence people's preferences? In order to test this, the results of the 1999 and 2003 general elections and the 2002 local elections in Estonia, as well as the results of current public opinion surveys, were compared to the coverage given to the campaigning parties in the largest Estonian newspapers. The analysis showed that the coverage of political parties in the print media, as determined by the frequency of valuative notations, described the election results to a great extent. It is noteworthy that a change in media content was followed by a change in public opinion. At the same time, an accumulation effect became obvious: The voters' preferences for political parties accumulated diachronically during the course of several weeks based on the information that was available to them.
\end{abstract}

Keywords: media influence, accumulation effect, regression models, collinearity, S-curve.

\section{Introduction}

To speak of the importance of the media is to speak of its influence on people. However, measuring and evaluating that influence is still a very inexact science. Even today, researchers are moving within the field of assumptions, although for years studies of influence have been held to be the engine of research in mass communication (see Katz \& Lazarsfeld 1955: 18).

Some years ago, University of Liverpool Professor John Corner (2000: 379) wrote: "If we pose the rather unhelpfully general question 'Are the media influential or not', then it is hard to imagine any intelligent person saying 'No'." This is undoubtedly so, although in specialized publications one may find numerous examples in which researchers time and again doubt that the media have a great influence. This does not mean that those who hold similar views are unintelligent people. The problem may be more related to the difficulties associated with researching mass media effects. sity, Siili 14, EE-Tallinn 13413/Minister of Culture of the Republic of Estonia (from 2005) 
Technically, it is relatively simple to show media effects on the basis of a single isolated event, for example, on the basis of a single election outcome. Even in the current article, statistics from three elections are presented. But the fact that mass media content more closely reflects the election outcome as election day approaches does not necessarily tell us anything about media effects, no matter how complicated our analytical techniques are. Many logical problems are involved, which lead to the important question: What changes first - media content or public opinion? It is necessary to know which influences the other. By comparing media content analysis data and the statistics from current public opinion surveys, the author attempts to answer this question.

In so doing, the cumulative effect is encountered. Within the framework of the agenda-setting theory, many scholars have shown the cumulative nature of the agendasetting process (Iyengar and Kinder 1987; Neumann 1990; Brosius and Kepplinger 1992). A few studies have attempted to discover the optimal time lag between the appearance of news reports about an issue and subsequent shifts in the public's perceptions of the importance of the issue. Michael Salwen has found that "the period of peak or optimal relationship between the public agenda and the media agenda appears after the accumulation of about eight to ten weeks of media coverage" (Salwen 1988: 106). Wayne Wanta and Yu Wei Hu have reported similar findings using time periods of four weeks prior to public opinion surveys. Among other things, they proved that stories with high levels of conflict produce the strongest agenda-setting effects (Wanta and $\mathrm{Hu}$ 1993: 260). In 1997, Wanta made his conclusions more precise, noting that the optimal time lag is between one and ten weeks, primarily depending on the type of media (Wanta 1997: 149-150).

These results help determine the length of the time frame for this analysis. Simultaneously with attempting to find the answer to the main question ("what changes first?"), the author's goal is to show how the accumulation effect comes about. However, there is a problem that must be considered: Describing media effects in terms of simple time lags presupposes that the presentation of the issue or actor brings with it, after a certain time, a certain effect. Thus, the prior media coverage of the same issue or actor is left unaccounted for. What is of interest is the aggregation of the influence of mass media during the period of observation. In making these analyses, the author does not rely on the agenda-setting theory or observe issues, but rather focuses on the coverage given to the political parties by the media.

Before proceeding, it must be clarified that when speaking of media influence one must keep in mind the designation that was offered as early as 1963 by German media scientist Gerhard Maletzke (1963:190) and that is now generally accepted (see Merten 1999: 334; McLeod et al. 2002: 218): Media influence is a change in the knowledge, attitudes and actions of people as a result of exposure to media messages. The central word here is "change" - when speaking of media influence one is always speaking of changes, differences from what existed previously in the same group, or differences in relation to another population.

The current article remains on the macro level and observes the influence of the print media on Estonian voters between the years 1999-2003. During this period, four elections were held in Estonia: the Riigikogu (parliamentary) elections on March 7, 1999, and March 2, 2003; the local elections on October 20, 2002; and the presidential election on September 21, 2001. Although there are sufficient specific data in connection with the latter, these are not included in the current analysis because the presidential election differs too greatly from the other elections. For the elections held in 1999, 2002 and 2003, it is possible to compare the media coverage given to political parties with the number of votes they received in the election. The president, however, is not popu- 
larly elected, but chosen by either the parliament or an electoral college composed of members of the parliament and the representatives of municipal governments. Therefore, the data from presidential elections are not comparable to the data from the other elections.

The current research is approached with the understanding that an election campaign is primarily a communication campaign, and that the distribution of political information prior to elections is an important part of the struggle for power. The election campaign may be described as a battle for influence over the public within a designated space by political parties and their candidates. At the same time, publicity is merely a means for the actors. Their real objective in the election campaign is the power that enables them to make political decisions and have control over their implementation.

In order to gain the maximum number of votes, a political party must inspire the voters' support. As a means to achieve this goal, it has at its command two basic communication sources: the party's own organization and the mass media (Schmitt-Beck, Pfetsch 1994: 110). In Estonia, the influence of the first is small (Ruutsoo 1998: 40). For this reason, by an overwhelming margin, the media may be considered to be the most important source of political information.

All forms of communication are based on making choices. Journalists are constantly choosing words and perspectives through which they describe the actors to the public via their stories. Newspaper articles are by their nature constructions that highlight certain characteristics of the actors and hide others. In this manner, they help to shape the citizens' perceptions of the actors. The theory of mass opinion recognizes that citizens' opinions are substantially influenced by certain frames and cues contained in media coverage (Fan 1988, Pan and Kosicki 1997, Shah et al. 2002). It is presumed that journalistic interpretations of the activities of political parties are expressed by their positive, negative or neutral evaluations (in a general sense), and it is of primary interest to study how those evaluations are related to the voting preferences of citizens.

\section{Method and Data}

Strictly speaking, the study of media influence presumes an input-output analysis, in which the input is media information and the output is the knowledge, opinions and attitudes of individuals. The method for measuring the first is content analysis and the method of measuring the second is surveying public opinion. ${ }^{1}$

A total of seven publications were analyzed during the 1999 elections: two that call themselves quality dailies: Postimees and Eesti Päevaleht; the two largest circulation national tabloids: Õhtuleht and Sõnumileht; the business newspaper Äripäev; and the two largest circulation weeklies: Eesti Ekspress and Maaleht.

During the 2002 and 2003 elections, the number of newspapers analyzed for content numbered 10, six of which were also analyzed in 1999: Postimees, Eesti Päevaleht, the national circulation tabloid SL Õhtuleht (in 2000 Õhtuleht and Sõnumileht merged under the banner of SL Õhtuleht), Äripäev, Eesti Ekspress and Maaleht, and in addition to these, four Russian language newspapers with circulation throughout Estonia: dailies Molodjoz Estonii and Estonia together with the weeklies Den za Dnjom and Nedelja Plus Vesti. The data characterizing the influence potential of those publications are presented in Tables 1 and 2 .

In this study, the mass media under consideration constitute the print media. Although, in accordance with widespread opinion, television is considered to be more influential than the print media, many authors allude to the fact that newspapers have greater in- 
Table 1. Data which Characterizes the Quantitative Influence Potential of Publications during the Spring of 1999

\begin{tabular}{lcccc} 
Newspaper & Frequency of issue & Circulation & $\begin{array}{c}\text { Number of } \\
\text { readers }\end{array}$ & $\begin{array}{c}\text { Percent of } \\
\text { readership (cover) }\end{array}$ \\
\hline Postimees & 6 times a week & 58,200 & 237,000 & 21.5 \\
Eesti Päevaleht & 6 times a week & 48,600 & 229,000 & 20.8 \\
Õhtuleht & 6 times a week & 46,400 & 128,000 & 11.6 \\
Sõnumileht & 6 times a week & 29,400 & 151,000 & 13.7 \\
Äripäev & 5 times a week & 17,000 & 78,000 & 07.1 \\
Eesti Ekspress & once a week & 47,100 & 194,000 & 17.6 \\
Maaleht & once a week & 42,000 & 180,000 & 16.3 \\
\hline
\end{tabular}

Source: Newspaper Association of Estonia (Eesti Ajalehtede Liit); BMF Gallup Media (Balti Meediateabe AS).

Table 2. Data which Characterizes the Quantitative Influence Potential of Publications during January-February 2003

\begin{tabular}{lcccc} 
Newspaper & Frequency of issue & Circulation & $\begin{array}{c}\text { Number of } \\
\text { readers }\end{array}$ & $\begin{array}{c}\text { Percent of } \\
\text { readership (cover) }\end{array}$ \\
\hline Postimees & 6 times a week & 61,500 & 246,000 & 23.5 \\
Eesti Päevaleht & 6 times a week & 33,500 & 136,000 & 13.0 \\
SL Õhtuleht & 6 times a week & 65,600 & 279,000 & 26.7 \\
Äripäev & 5 times a week & 20,700 & 74,000 & 07.1 \\
Estonia & 6 times a week & 6,100 & 37,000 & 03.6 \\
Molodjoz Estonii & 6 times a week & 7,200 & 56,000 & 05.4 \\
Eesti Ekspress & once a week & 44,700 & 140,000 & 13.4 \\
Maaleht & once a week & 49,000 & 156,000 & 14.9 \\
Nedelja Plus Vesti & once a week & 20,900 & 66,000 & 06.3 \\
Den za Dnjom & once a week & 18,600 & 71,000 & 06.8
\end{tabular}

Source: Newspaper Association of Estonia (Eesti Ajalehtede Liit); TNS Emor, Estonian Media Study (Eesti Meediauuring). Period: December 2002 - February 2003.

fluence in mobilizing voters than does television (Norris et al. 1999:101). Newspapers are also considered to be more effective in setting the agenda (McCombs, Gilbert 1986: 9-10).

This conclusion is also supported by a previous study conducted by the author. This study showed that, at least in Estonia, the influence of television on mobilizing the voters and formulating their preferences tended to be weaker than the influence of the print media. In searching for the reasons, it may be noted that in Estonia, there are three television channels: the state-sponsored Estonian Television and two commercial channels, Kanal 2 and TV3 - and this in a state with a total population of only 1.36 million. Due to the small audience and modest amount of advertising that the local advertising market can support, the amount of original program production by the television channels is small, and the news programs of all television channels are based on the news items provided to them by news agencies.

Usually, journalists pay careful attention to the media opinion leaders and to a great extent select themes for coverage and the manner in which these themes are handled (Donsbach 1996: 86). In Estonia, the leading media opinion leaders are the newspapers 
Postimees, Eesti Ekspress and Eesti Päevaleht, from which the television channels pick up the most essential issues. Often press journalists also act as hosts, moderators or authors of politically oriented television programs. For this reason, television's impact on distributing political information in Estonia is modest. Although the readers of quality newspapers represent only a small part of the total population, these media influence the reporting in other media and their content may be seen as a reliable indicator of overall trends in media coverage.

The political actors, whose exposure was studied and compared in the aforementioned publications, are all political parties that participated in the elections with their own electoral lists of candidates. During the 1999 Riigikogu (parliamentary) elections, there were 12 such political parties: Reform Party (RefP), Center Party (CP), the Moderates (M), Pro Patria Union (PPU), Rural People's Party of Estonia (RPPE), Coalition Party (CoalP), Russian Party in Estonia (RPE), United People's Party of Estonia (UPPE), Farmers Assembly (FA), Christian People's Party (CPP), Development Party (DP) and the Estonian Blue Party (EBP).

Eleven political parties participated in the 2003 elections: Reform Party, Center Party, the Moderates, Pro Patria Union, the People's Union of Estonia (PUE), which became the successor to the Rural Party of Estonia, Res Publica ${ }^{2}$ (ResP), which was founded in 2001, United People's Party of Estonia (UPPE), Russian Party in Estonia (RPE), Christian People's Party, Independence Party (IP) and the Estonian SocialDemocratic Labor Party (ESDLP).

Estonia lacks a legal definition of "election campaign" and therefore its duration has not been defined. De facto, the election campaign begins after the elections have been officially announced and intensifies during the last five or six weeks prior to the election. This also determined the time frame of the analysis, which in 1999 lasted from Monday, January 4 to Saturday, March 6. January 4 was the first workday of 1999, and nine weeks remained before the parliamentary elections. March 7 was Election Day. All of the most essential pre-election events fit into this time frame, and at the same time this was the most intensive period of the election campaign. The media content analysis during the 2002 and 2003 election campaign periods was carried out from June 2002 until March 2003. Both the local elections that took place on October 20, 2002, and the general elections of March 2, 2003, fit into this time span. During that period, all of the media valuations of every political party that participated in the elections were counted and analyzed.

The code words for the content analysis were notations of the names of the political parties participating in the elections. The counters selected notations from news items, editorials and opinion articles (op-ed pieces). Upon discovering a notation within the text, the counter had to ascertain the context - positive, neutral or negative - in which the notation appeared. The number of such notations in the text was interpreted as an indicator of the intensity of the attitude and value judgments.

In conducting this study, six sets of data were used: election results, results of public opinion polls (surveys), the positive, negative, and neutral notations of political parties and positive advertising. ${ }^{3}$ The first two were analyzed as dependent variables and the last four as explanatory variables. For purposes of comparison, the figures are placed on the same base, expressing the share in percentages in all cases: in the case of election results, each political party's share of votes in percentages; in the case of media information, the party's positive and negative assessments, and its share of neutral references in the total. ${ }^{4}$ Hereafter, the letter $y$ signifies election results, $y_{o s}$ signifies the results of public opinion surveys, $x_{p}$ the positive valuations of the political parties, $x_{e}$ the 
neutral mentions, $x_{n}$ the negative valuations, while $x_{a}$ signifies positive advertising. The notation frequency of political parties $\left(x_{z}\right)$, which is expressed as the sum of positive, neutral and negative valuations $\left(x_{z}=x_{p}+x_{e}+x_{n}\right)$, has also been used as an explanatory variable. The notations of political parties that participated in the elections were counted in the observed publications, amounting to a total of 7,830 times in 1999, and 14,504 times in 2002 and 2003.

\section{Regression Models}

How are the election results tied to input variables? An attempt is made to measure the strength of these relationships using multiple regression and correlation, which also make it possible to predict output variables. In the interest of acquiring a complete picture, it is necessary to merge into the model all four input variables: $x_{p}, x_{e}, x_{n}$ and $x_{a}$. However, given the fact that there is a noticeable correlative relationship among the predictors, there is the danger of collinearity. In addition, collinearities involving three or more variables are relatively difficult to detect. The possible underlying reasons for the collinearity will be discussed later in this article. Let it be noted here that the lack of independence among predictors is inherent in this type of data: it is not generated by design. This means that collection of additional data does not eliminate the problem of collinearity. Collinearity does not affect the ability of a regression equation to predict the response, but serious correlations among argument variables will lead to inflated magnitudes of the estimates and inflation in the variances of these estimates (Hocking 2003: 166). In order to preclude this possibility, it is necessary to eliminate explanatory variables that are more closely tied to other input variables than to the output variable. Making the selection also presumes that the variance inflation factor (VIF) must be calculated. As a rule of thumb, Hocking (2003: 168) suggests using $\mathrm{VIF}_{j}>10$ as an indication of collinearity.

Following that suggested approach, the argument variable in the 1999 model is positive media coverage of political parties $\left(x_{p}\right)$; in 2002 positive $\left(x_{p}\right)$, neutral $\left(x_{e}\right)$ and negative $\left(x_{n}\right)$ media coverage; 5 and in 2003 positive $\left(x_{p}\right)$, neutral $\left(x_{e}\right)$ and negative $\left(x_{n}\right)$ media coverage and frequency of positive advertisements $\left(x_{a}\right)$. The data for the three linear regression models are presented in Table 3 - adjusted coefficient of determination ${ }^{6}$ (adjusted $R^{2}$ ), standard error $\left(s_{e}\right)$, significance of the model, standardized regression coefficients (Beta), and their significance. The election results in those models are assumed to be a function of the input variables.

Table 3 shows that in all three instances one may speak of the strong relationship between election results and how the different political parties were presented in the print media. However, because influence was defined as a change, the dynamics of the relationship coefficients prior to the election must also be observed. In order to accomplish this, the correlative relationship between election results and media coverage of political parties was studied week by week. Because for several of the observed weeks it was not possible to calculate and obtain statistically significant results for the multiple correlation coefficients between the three argument variables - positive, neutral and negative coverage - and the election results, the election results were compared with the frequency of media notations of political parties $\left(x_{z}\right)$.

As stated above, the frequency of notation is the sum of positive, neutral and negative coverage $\left(\mathrm{x}_{z}=x_{p}+x_{e}+x_{n}\right)$. Thus $\mathrm{x}_{\mathrm{p}}, \mathrm{x}_{\mathrm{e}}$, as well as $\mathrm{x}_{\mathrm{n}}$ show strong correlation with the response. However, when plotting linear relationships that appear in more than two dimensions onto a single multiple regression plane, the strength of the partial associa- 
Table 3. Linear Regression Models: Dependence of Election Results upon the Valuation of Political Parties in the Print Media and Advertising

\begin{tabular}{|c|c|c|c|c|c|c|}
\hline & \multicolumn{2}{|c|}{$\begin{array}{c}1999 \\
9 \text { pre-election weeks: } \\
\text { Jan. } 4 \text { - June 1, } 1999\end{array}$} & \multicolumn{2}{|c|}{$\begin{array}{c}2002 \\
8 \text { pre-election weeks: } \\
\text { Sept. 3 - Oct. 19, } 2002\end{array}$} & \multicolumn{2}{|c|}{$\begin{array}{c}2003 \\
9 \text { pre-election weeks: } \\
\text { Jan. 1, - Mar. 1, } 2003\end{array}$} \\
\hline Adjusted $R^{2}$ & \multicolumn{2}{|c|}{0.971} & \multicolumn{2}{|c|}{0.966} & \multicolumn{2}{|c|}{0.994} \\
\hline & \multicolumn{2}{|c|}{1.860} & \multicolumn{2}{|c|}{1.395} & \multicolumn{2}{|c|}{1.264} \\
\hline Significance & \multicolumn{2}{|c|}{0.000} & \multicolumn{2}{|c|}{0.004} & \multicolumn{2}{|c|}{0.000} \\
\hline Arguments & Beta & Sig. & Beta & Sig. & Beta & Sig. \\
\hline$x_{p}$ & 0.987 & 0.000 & 1.545 & 0.004 & 1.445 & 0.004 \\
\hline$x_{e}$ & - & - & -1.909 & 0.029 & -0.845 & 0.041 \\
\hline$x_{n}$ & - & - & 1.421 & 0.029 & 1.125 & 0.007 \\
\hline$x_{a}$ & - & - & - & - & -0.767 & 0.005 \\
\hline
\end{tabular}

tion between $x_{e}$ and $x_{n}$, on the one hand, and $y$, on the other, becomes weaker. A noteworthy effect deriving from the relationship among the explanatory variables themselves is also added. For this reason, the numerical value of the multiple coefficient of determination is greater than the coefficient of determination between the output variable and frequency of notation $\left(r_{y x_{z}}^{2}\right)$. Second, the relationship between the frequency of notation and the dependent variable is weaker than the relationship between positive coverage and the response, because in the first instance, the influence of other variables is also reflected. The association between neutral valuations $\left(x_{e}\right)$ and the response was negative in all models observed - this result appeared as negative values for standardized regression coefficient (Beta) as well as for the partial coefficient of correlation. As a result, it may be concluded that $\left.\left.R_{y \cdot x_{p} x_{e} x_{n}}^{2}\right\rangle r_{y x_{p}}^{2}\right\rangle r_{y x_{z}}^{2}$. In all instances where $x_{z}$ is an independent variable, the relationship between the frequency of notation and the dependent variable is relatively modest (see Tables 6 and 7 and Figure 2).

Figure 1 depicts the data relating to the dynamics of the coefficients of determination $\left(r_{y x_{z}}^{2}\right)$ between the March 2, 2003, election returns and the notation frequency of the political parties by month from June 2002 until March 2003. Because the number of political parties participating in the elections is inevitably limited, the coefficients of determinations are statistically significant when the probability of the null hypothesis is $p \leq 0.05$.

Figure 1 shows that the relationship between media content and the March 2, 2003 election results is noticeable. The value for the coefficient of determination changed noticeably prior to the election. It rose as the local municipal elections approached from September to October from 0.51 to 0.64 (it was noted above that the adjusted multiple coefficient of determination for the October 20, 2002, local election returns and media coverage was 0.97 , clearly significantly greater). Thereafter, in December, it declined to 0.47 and rose again in January to 0.72 . In the last month prior to the elections, it rose to 0.75 . It may be concluded that the coefficient of determination changed.

\section{The Chicken or the Egg?}

What do these findings show? First, it may be observed that the closer we come to Election Day, the more closely the content of the media expressed the outcome of the 
Figure 1. The Coefficients of Determination between March 2, 2003, Election Results and the Notation Frequency of the Political Parties during June 2002 February 2003

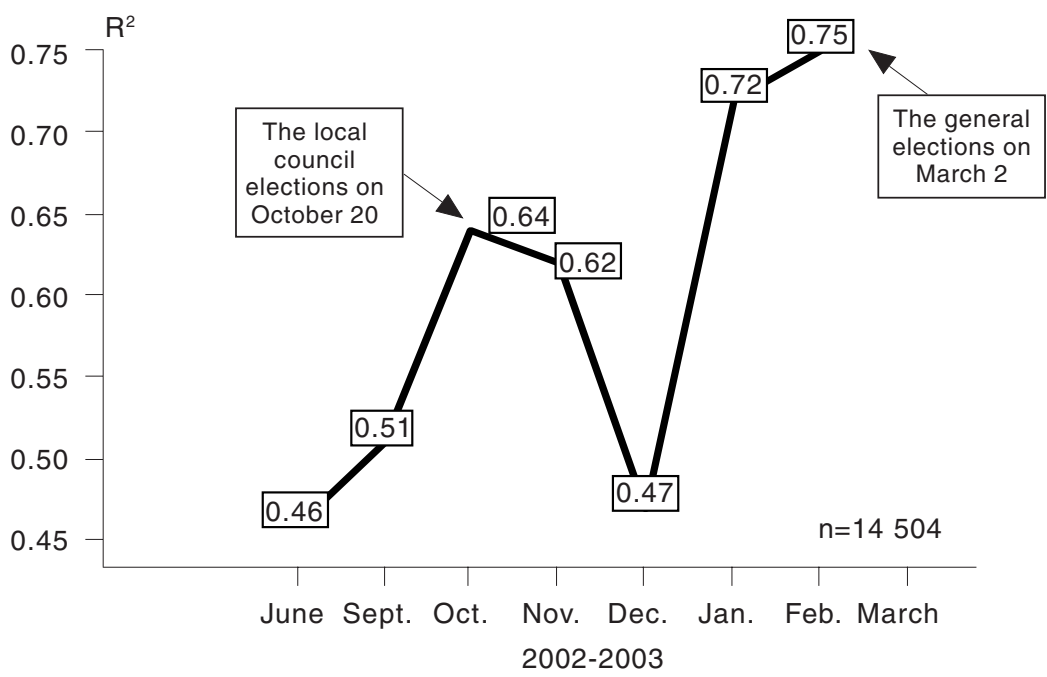

upcoming election. And second, the political parties that received a relatively greater number of votes in the election received more coverage in the media than did other political parties. There is nothing new in either finding: In comparing the content analysis data and the results of public opinion surveys, the same conclusions have been reached frequently. However, the question is: Which came first, the chicken or the egg? Theoretically, it may be assumed that, in the first case, the media content simply reflected the change in public opinion. In the second instance, however, it is possible, instead, that the popularity of the political parties and candidates influenced their positive, negative or neutral handling by the media. It is natural to assume that strong and popular political parties will be more extensively covered by the media than will weaker or less popular political parties. Time and time again, attention has been focused on this possibility (see Norris et al. 1999: 49). So, who influenced whom: Did the people's preferences for political parties influence the media or did the media influence the people's preferences for political parties?

By comparing the leading daily and weekly newspapers' coverage of the political parties participating in the 1999 and 2003 parliamentary elections immediately prior to the elections, the preference shown for some and the disfavor shown to others became clear. This could be seen in news stories as well as opinion pieces. However, these relationships of preference and disfavor were not very closely tied to the popularity of the political parties, and it cannot be said that the latter influenced the positive or negative handling of a political party by the media.

Thus, the question remains: Which changed first - the media tone or public opinion? In searching for an answer to that question, one may compare the results of public opinion polls conducted prior to the 2003 elections with the data of the media content analysis.

Prior to the 2003 parliamentary elections, numerous public opinion polls explaining voters' support for political parties were conducted between December 2002 and March 2003. Four of them were carried out by the research firm Emor. The results of those 
public opinion surveys have been published by Emor analyst Aivar Voog (Voog 2003). The Emor polls were conducted between November 27 and December 18, 2002, and between January 8-15, February 5-12 and February 18-24 in 2003. On all occasions, 500 people were polled. In addition to that, Turu-uuringute AS [Market Research, Inc.] carried out a survey from January 31 to February 7, 2003, in which 1,000 persons were polled (PM 2003). The results of the aforementioned polls are given in Table 4.

Table 4. Results of Public Opinion Polls Conducted Prior to the 2003 Parliamentary Elections (support for political parties - percentage of legal age citizens who had the firm intention of voting)

\begin{tabular}{lccccc}
$\begin{array}{l}\text { Survey } \\
\text { organization }\end{array}$ & Emor & Emor & $\begin{array}{c}\text { Turu- } \\
\text { uuringute AS }\end{array}$ & Emor & Emor \\
\hline Political Party & Noc. 27 18,2002 & Jan. 8-15, & Jan. 31- & Feb. 5-12, & Feb.18-24, \\
Dec. 2003 & Feb. 7, 2003 & 2003 & 2003 \\
\hline RefP & 13 & 13 & 13 & 20 & 15 \\
CP & 27 & 26 & 30 & 31 & 27 \\
M & 3 & 6 & 5 & 4 & 7 \\
PPU & 6 & 8 & 4 & 6 & 7 \\
PUE & 5 & 6 & 6 & 3 & 11 \\
ResP & 23 & 21 & 24 & 14 & 16 \\
& $\mathrm{n}=500$ & $\mathrm{n}=500$ & $\mathrm{n}=1000$ & $\mathrm{n}=500$ & $\mathrm{n}=500$ \\
\hline
\end{tabular}

Source: Voog 2003; PM 2003.

The results of the surveys are compared with the media content data prior to conducting the survey and during the period of the survey, using equal time spans. If the poll was conducted during a seven-day period, for example, the period observed prior to the election was also seven days in duration. The survey results are observed as the dependent variable and the frequency of notation of political parties in the print media $\left(x_{z}\right)$ as the explanatory variable. The values for the coefficients of determination between the survey results and the notation frequency of political parties are presented in Table 5.

In all three instances, the value for the coefficient of determination before the polling was markedly greater than during the polling period. This finding is important: One can see the typical lagged correlation. One can observe here the classical pattern of media influence: The media sets the public opinion tenor, which the public adopts as its opinion at some later point in time. From this it can be concluded that the coverage by the media influenced public opinion.

At first glance, this conclusion is not supported by the data collected in the survey conducted by Emor in the beginning of February. Immediately prior to the poll conducted from February 5-12, the coefficient of determination for the notation frequency of political parties and the results of the public opinion poll $\left(r_{y_{o z} x_{z}}^{2}\right)$ was 0.86 and during the polling period it was 0.96 (see Table 6).

From this it can be seen that media apparently followed more closely the public opinion that prevailed at the moment. However, in drawing this conclusion it must be presumed that the observed publications had not written anything previously about political parties, or that the recipients had completely forgotten the information they had received. This, however, is obviously not the case. It is easy to be convinced that this is so by extending the time period prior to the polling period and taking into account the earlier coverage given to political parties in the media. 
Table 5. Survey Findings ( $\left.y_{0 .}\right)$ and Results of the Content Analysis in Percent ( $\left.x_{z}\right)$, Coefficients of Determination $\left(r_{y x}^{2}\right)$ between the Survey Findings and Frequency of Notion of Political Parties for the Periods Preceding the Surveys and during the Polling Periods in December 2002 and January 2003.

\begin{tabular}{|c|c|c|c|c|c|c|c|c|c|}
\hline & $\begin{array}{c}\text { Emor } \\
\text { Nov. 27- } \\
\text { Dec. 18, } \\
2002\end{array}$ & $\begin{array}{c}\text { Before } \\
\text { Nov. } \\
5-26 \\
2002 \\
\end{array}$ & $\begin{array}{c}\text { Polling } \\
\text { period } \\
\text { Nov. 27- } \\
\text { Dec. 18, } \\
2002\end{array}$ & $\begin{array}{l}\text { Emor } \\
\text { Jan. } \\
8-15 \text {, } \\
2003\end{array}$ & $\begin{array}{c}\text { Before } \\
\text { Jan. } \\
3-7 \\
2003 \\
\end{array}$ & $\begin{array}{c}\text { Polling } \\
\text { period } \\
\text { Jan. } \\
8-15 \\
2003 \\
\end{array}$ & $\begin{array}{c}\text { Turuuurin- } \\
\text { gute AS } \\
\text { Jan. 31- } \\
\text { Feb. 7, } \\
2003\end{array}$ & $\begin{array}{c}\text { Before } \\
\text { Jan. } \\
23-30 \\
2003 \\
\end{array}$ & $\begin{array}{c}\text { Polling } \\
\text { period } \\
\text { Jan. 31- } \\
\text { Feb. 2, } \\
2003\end{array}$ \\
\hline & $y_{o s}$ & $x_{z}$ & $x_{z}$ & $y_{o s}$ & $x_{z}$ & $x_{z}$ & $y_{o s}$ & $x_{z}$ & $x_{z}$ \\
\hline RefP & 13 & 23.2 & 14.1 & 13 & 20.4 & 22.7 & 13 & 21.1 & 19.7 \\
\hline $\mathrm{CP}$ & 27 & 29.1 & 32.1 & 26 & 34.0 & 33.6 & 30 & 29.6 & 34.5 \\
\hline M & 3 & 8.3 & 12.6 & 6 & 8.1 & 11.1 & 5 & 10.8 & 8.6 \\
\hline PPU & 6 & 14.2 & 17.2 & 8 & 13.3 & 8.9 & 4 & 10.7 & 12.6 \\
\hline PUE & 5 & 5.9 & 8.0 & 6 & 10.7 & 10.1 & 6 & 10.0 & 11.1 \\
\hline ResP & 23 & 15.6 & 11.1 & 21 & 13.3 & 12.1 & 24 & 17.5 & 12.0 \\
\hline$r_{y x}^{2}$ & - & 0.62 & $\begin{array}{l}\text { nonsig- } \\
\text { nificant }\end{array}$ & - & 0.63 & 0.56 & - & 0.78 & 0.56 \\
\hline$n$ & - & 409 & 389 & - & 532 & 660 & - & 629 & 768 \\
\hline
\end{tabular}

Table 6. Survey Findings $\left(y_{o s}\right)$ and Results of the Content Analysis in Percent ( $\left.x_{z}\right)$, Coefficients of Determination $\left(r_{y x}^{2}\right)$ for the Results of Public Opinion Polls and the Notation Frequency of Political Parties Prior to and during the Polling Periods in February 2003

Emor Before Pollingperiod Emor Before Pollingperiod

Feb. 5-12, Jan. 28-Feb.4, Feb. 5-12, Feb. 18-24, Feb. 11-17, Feb. 18-24,

$\begin{array}{lllll}2003 & 2003 & 2003 & 2003 & 2003\end{array}$

\begin{tabular}{lcccccc} 
& $y_{\text {os }}$ & $\mathrm{x}_{z}$ & $\mathrm{x}_{\mathrm{z}}$ & $\mathrm{y}_{\text {os }}$ & $\mathrm{x}_{z}$ & $\mathrm{x}_{z}$ \\
\hline RefP & 20 & 22.1 & 18.5 & 15 & 15.8 & 17.5 \\
CP & 31 & 31.4 & 30.5 & 27 & 25.3 & 21.6 \\
M & 4 & 9.8 & 11.0 & 7 & 13.3 & 13.8 \\
PPU & 6 & 12.9 & 12.2 & 7 & 12.2 & 14.3 \\
PUE & 3 & 11.7 & 9.0 & 11 & 10.9 & 11.4 \\
ResP & 14 & 11.0 & 17.7 & 16 & 20.1 & 19.4 \\
$r^{2}{ }_{y x}$ & - & 0.86 & 0.96 & - & 0.85 & 0.73 \\
$\mathrm{n}$ & - & 691 & 745 & - & 692 & 857 \\
& - & $p \leq 0.01$ & $p \leq 0.01$ & - & $p \leq 0.01$ & $p \leq 0.05$ \\
\hline
\end{tabular}

The duration of the ideal time lag between the appearance of media coverage and the change in public opinion that takes place is not known. It has been claimed in research associated with the agenda-setting approach that the time lag may be as long as ten weeks and depends primarily on the type of media (see Wanta 1997: 149-150). In all likelihood, it is possible to experimentally verify this by searching for the time lag during which the correlation between the media coverage and the results of the public opinion surveys is greatest. Jumping ahead, it may be said that, because the correlation coefficients in this study are very high, an ideal time lag has been used. On the other hand, it is not known how long it takes for information learned from mass media to be forgot- 
ten. The problem has been solved in the current study by taking into consideration the content of the media starting from January 3, 2003, until the February polling periods, i.e., by extending the time prior to the polling period to the beginning of January. This time lag fits into the period mentioned by Wayne Wanta.

Table 7 shows that by increasing the time period prior to conducting the poll from seven days to four and a half weeks (January 3 to February 4), the coefficient of determination between the results of the public opinion polls and the notation frequency of political parties increases from 0.86 to 0.98 .

Table 7. Survey Findings ( $\left.y_{0}\right)$ and Results of the Content Analysis in Percent ( $x$ ), Coefficients of Determination $\left(r_{v x}^{2}\right)$ for the Results of Public Opinion Polls and the Notation Frequency of Political Parties During and Prior to the Polling Periods Beginning in January - February 2003

\begin{tabular}{lcccccc} 
& Emor & Before & Pollingperiod & Emor & Before & Pollingperiod \\
& $\begin{array}{c}\text { Feb. 5-12, } \\
2003\end{array}$ & Jan. 3-Feb.4, & Feb. 5-12, & Feb. 18-24, & Jan. 3-Feb.17, & Feb. 18-24, \\
& 2003 & 2003 & 2003 & 2003 & 2003 \\
& $\mathrm{y}_{\text {os }}$ & $\mathrm{x}_{\mathrm{z}}$ & $\mathrm{x}_{\mathrm{z}}$ & $\mathrm{y}_{\text {os }}$ & $\mathrm{x}_{\mathrm{z}}$ & $\mathrm{x}_{\mathrm{z}}$ \\
\hline RefP & 20 & 22.9 & 18.5 & 15 & 15.8 & 17.5 \\
CP & 31 & 29.9 & 30.5 & 27 & 25.3 & 21.6 \\
$\mathrm{M}$ & 4 & 9.5 & 11.0 & 7 & 13.3 & 13.8 \\
PPU & 6 & 12.3 & 12.2 & 7 & 12.2 & 14.3 \\
PUE & 3 & 9.6 & 9.0 & 11 & 10.9 & 11.4 \\
ResP & 14 & 15.1 & 17.7 & 16 & 20.1 & 19.4 \\
$r^{2}{ }_{y x}$ & - & 0.98 & 0.96 & - & 0.87 & 0.73 \\
$\mathrm{n}$ & - & 2712 & 745 & - & 3975 & 857 \\
& - & $p \leq 0.01$ & $p \leq 0.01$ & - & $p \leq 0.01$ & $p \leq 0.05$ \\
\hline
\end{tabular}

Hence it is clear that the media content changed first and then public opinion followed. Moreover, the relationship between the content observed over a longer period of time and the results of the polls shows that public opinion accumulates diachronically on the basis of the available information. By its nature, it is a composite that is shaped not only by the media information of the moment, but also by the time lag between the information presented in the media and the changes that take place in the perception of the audience. This may range from a few days to many months in duration.

Figuratively speaking, one may compare public opinion with a Napoleon cake - it has several layers of previous and more recent media information. New coverage or valuations are given to the political parties on a daily basis, and each new media message forms a new layer influencing the layer that came before and that comes after. Something is forgotten and something is remembered, one issue forces another into the background or is itself influenced by the information received earlier.

The basic idea of the accumulation (or cake) model is that the mass media express values in connection with certain actors in their content, which contains news information as well as opinions. These actors may be political parties or individuals. The same valuation is later echoed in the minds of the recipients. The information offered at the next moment contains new coverage, which after a period of time is again reflected in the preferences of the recipient. However, the public's preferences are not echoed only by the media's latest segment of valuation, but by prior coverage as well. This becomes apparent in the relationship between the results of the lengthier period of content analysis and public preferences. 
This effect is not based only on the direct influence of the media. The recipient is active in the communication process and creates his own vision based on media information. The influence of media information is amplified by the virtual consensus that forms in the media public sphere - the recipients perceive that other people also receive the same media information (see Merten 1999: 110-111). Through this, a communications system is formed, based not on real presence, but on the relationship of the participants with virtual perception. The relationship does not form only between the medium and the recipient, but virtually also between all individuals who are believed to have received the same media item. In this manner, the recipients keep in mind the opinions believed to be held by others, which, in turn, increases the influence of the media. Diana Mutz has pointed out that media coverage does not directly affect individual opinions, but mass media are the primary source of people's perceptions of collective opinion and experience (Mutz 1998: 77). This conclusion is consistent with numerous previous studies indicating that sociotropic voting is much more common than pocketbook voting (see Kinder and Kiewiet 1979, 1981; Lewis-Beck 1988: 56).

Interpersonal communication also plays a vital role in this process. People discuss the events of the day and media information among themselves, and on that basis form their opinions. At the same time, the strong relationship between election or survey results and media content shows that in interpersonal communication the discussion centered mostly on themes and events offered by the mass media, and that personal evaluations of political parties did not differ very much from their evaluations in the mass media.

The voters' preferences were formed layer upon layer on the basis of what was presented via public communications. The aforementioned applies not only with regard to mass media content and opinion polls, but also in the case of election results. Figure 2 shows the coefficients of determination between the notation frequency of political parties and the election results $\left(r_{y x_{z}}^{2}\right)$ during the eight weeks prior to the elections in

Figure 2. Coefficients of Determination between Election Results and Notation Frequency in 2003

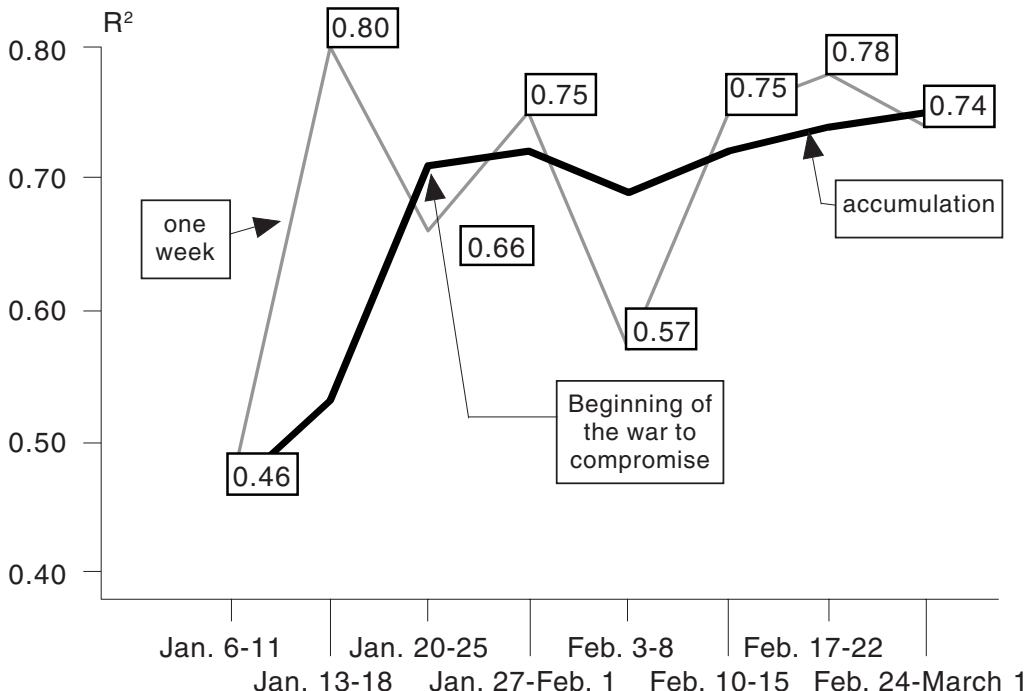

2003 
2003. At the same time, the relationships between the concurrent week's media coverage and accumulated media information and the election results have been compared. In the last instance, the data from prior weeks beginning with the first week of January have been added to the notation frequency of political parties during the current week $\left(x_{z}\right)$. In other words, the period of observation has been extended to the beginning of January.

In Figure 2, the narrower line depicts the concurrent weeks' coefficients of determination, and the thicker line depicts the accumulation dynamics. It can be seen that the coefficients of relationship between one-week notation frequency data and elections results fluctuate in rather large amplitudes. However, the determination coefficient of the combined results constantly increases and in quite an even manner. The basic flow of the process of forming preferences for political parties is depicted by the latter. In following the dynamics of the coefficient of determination week by week in 2003, it may be observed that the rise of the accumulation curve stopped in the penultimate week of January (Jan. 20-25). Exactly that week, the war to compromise the opposing candidates started with the so-called Seppik scandal ${ }^{7}$.

\section{Discussion}

It became clear that the frequency of valuations given to political parties in the observed print media described the election results to an unexpectedly great extent. However, on the basis of these results, may one speak of the influence of the media? Strictly speaking, the correlation coefficient offers an answer only to the question: Are two or more variables related to each other? But this may not indicate a direct cause and effect relationship. Even a statistically significant regression does not necessarily mean that $\mathrm{x}$ causes a change in y. It only shows how two or more variables are related to each other, and it enables us to predict one variable based on the other.

According to Frederick Mosteller and John W. Tukey (1977: 260-261), it may be said that media influence as a causal relationship has three conditions. First, there must be consistency. This means that the relation between $\mathrm{x}$ and $\mathrm{y}$ in the examined population is consistent at least in direction, perhaps even in amount. The second condition is responsiveness: If one can intervene and change $x$ for some individuals, their $y$ 's will respond accordingly. The third condition is a stable mechanism through which the media, as a "cause", may be tied to "effects". Different from the first two conditions, which can be proved empirically and experimentally, this mechanism can be verified only by "constructing a detailed mechanism, and supporting the correspondence between each step in the mechanism and that in the process under study." (id.: 261.) Most of the time, relying upon only a statistical method will not be sufficient.

In the given instance, the first two conditions are met. In the case of all three observed elections, a permanent and quantitatively measurable relationship prevailed between $x$ and $y$, and this had a clear direction. Thus, one may not speak of the reciprocal dependence of the variables, where the observed factors appeared both as objects and subjects of influence. The election returns or results of the public opinion polls could not in any way influence the observed content of media, and for this reason the relationship of those variables can only be in one direction. It also may not be said that the popularity of political parties markedly influenced their handling by the media. However, in the observed media clear preferences among political parties did appear.

A clear chronological order appeared in comparing media content and the results of public opinion polls: The explanatory variable preceded the output variable. First the media distributed its valuations, and after some time elapsed, public opinion followed 
these valuations. Hence, public opinion accumulated diachronically and layer-uponlayer based on the available information. Public opinion was shaped not only by current information, but also to a large extent by media information from previous weeks. At the same time, the relationship was responsive: as $x$ changed, y responded accordingly.

With regard to the third condition - the mechanism of media influence - this has many steps and is complicated. Its complexity comes from the nature of any communication. In this case, we are dealing not with something absolute, but with relative quantities, with relationships between the media and the recipients and among the recipients themselves. They, in turn, are related to complicated psychological processes through which symbolic communication influences people's thoughts, feelings and actions.

The unraveling and untangling of all the threads of that mechanism here would be a hopeless undertaking, but it would be useful to direct the reader's attention to some circumstances. First, considering the high correlation coefficients, it should be noted that in proving the relationship between the valuation of political parties and election results, the influence of the media was measured for only those people who actually voted. Of the eligible voters, 57.4\% voted in the 1999 parliamentary elections (Estonian National Electoral Committee 1999); $52.5 \%$ in the 2002 local council elections (Estonian National Electoral Committee 2002) and 58.2\% in the 2003 parliamentary elections (Estonian National Electoral Committee 2003). Presumably, people who vote are primarily interested in information pertaining to political parties and the political debate in the media.

At the same time, there are very many people who did not vote and for whom information concerning political parties and candidates for election was not important to the same degree. From this it may be concluded that media exposure given to political parties is not the only ingredient of influence. Many authors (Converse 1970, Judd \& Milburn 1980, JeYábek 2001) have concluded that people's interest in politics and concentration upon the public debate in the media influences opinion much more than does media exposure of the problems that are the subject of those opinions. This interest and involvement may be compared with a catalyst in which the recipient's consciousness reacts to the material presented by the media within its sphere of influence.

Second, it must be emphasized that the term "causal relationship" used above in connection with the mechanism of media influence may be misleading. It does not mean a proportional and unidirectional process initiated by the sender - a simple causal relationship in the traditional sense of the stimulus-response scheme, where more and better stimuli results in a better effect. First of all, intent is not always essential in this mechanism. The relationship between media content and public opinion appears even when the communicator does not want it.

This is confirmed by an interesting fact. The value of the coefficient of determination decreased from 0.78 to 0.74 during the last week prior to the 2003 elections. The reason is instructive. All of the content parameters of the observed media differed markedly that week from the previous. In the belief that more frequent positive coverage of political parties by the media will always yield a better result, an effort was made by the parties immediately prior to the election to obtain greater coverage. This was also helped along by the print media itself, with its strong party-line tradition. The result was that the percentage of total positive coverage rose for the Reform Party during the final week prior to the elections to 54.2 percent, while the Center Party's negative coverage grew to 40.9 percent of the total negative coverage ${ }^{8}$. However, the influence of this coverage turned out to be opposite of what was expected.

The concept of the $S$-curve is familiar to advertising experts (see Stewart 1989). This means that in order for the advertisement to achieve a reward, it must be shown repeat- 
edly. The maximum effect is reached after some exposures following the initial exposure, but after that, each increase in effort will yield a decreased incremental reward. The relationship between positive coverage of political parties and the political preferences of individuals is also a curved line that peaks at some point. Advertising theory maintains that this line straightens out signaling a stable preference thereafter, but the author's study has shown that after peaking, there may be a decline. The 54 percent positive coverage that was afforded to one political party during the week prior to the elections seemed to have the effect of decreasing the number of votes it received in the elections.

Because in the case of negative coverage the curve slopes more gently, the non-linear relationship in connection with the coverage is weaker, and its part among many input variables is relatively modest. Thus, the frequent negative coverage of one political party did not have the expected result.

The oversimplification of handling the cause and effect relationship is also contraindicated by the fact that in all three instances the readership of the observed publications did not coincide with the entire electorate - there were always more people influenced than there were media message receivers. That fact points to the reality that impersonal influence (Mutz 1998) and reflexivity in the social dimension (Luhmann 1994: 119) have an essential role in forming election preferences: People hold the same opinions that other people around them have, and they believe what others believe. At the same time, the strong relationship between election results or public opinion polls and media content refers to the fact that the media were an essential source of information for those who voted, and that also in interpersonal communication mostly issues and events covered by the media were discussed. The fact is confirmed here that during election campaigns the media stimulate interpersonal discussion and interest, which in turn helps people to decide how to vote (McLeod et al. 2002: 236-237).

As already mentioned, election results were influenced by all the observed explanatory variables. At the same time, it became obvious that there was collinearity among them. This relationship was so strong that one was left with the impression that the same quantity of information is being observed under different names. In a certain sense this is true, because the media do not transfer information from the transmitter to the recipient, but offer interpretations and connotations from which the more or less autonomous recipient constructs a message that is acceptable to him in an attempt to decrease his own uncertainty. In their book, Autopoiesis and Cognition, Humberto Maturana and Vrancisco Varela provide a description of the inner nature of that process by comparing it to an instrumental flight in which the pilot sees only his instruments and makes decisions with their help concerning whether to remain on the same course or to change it (Maturana \& Varela 1980: 26). Thus, the pilot reacts only to the script. In a somewhat similar manner, the voter in a modern society uses the media as an instrument to enable him to orientate himself and to reduce his uncertainty. German communication scientist Jürgen Gerhards has defined mass media output as a substitute indicator on the basis of which the public forms its own preferences. According to Gerhards, citizens make their decisions based on incomplete information. They never know exactly what a political party has done in the past, what it intends to do in the future or to what extent the activities of one political party or one politician are in conformity with the their interests. Citizens attempt to compensate for the deficiency by using the media as substitute indicators (Gerhards 1991: 7).

The valuation of political parties and candidates is an important source of information to people prior to elections - information that increases their certainty of orientation and enables them to evaluate political parties and candidates. In the case of such 
evaluations, the different parameters of media content are for the evaluator essentially one piece of related information. Clumps of these variables measure the same thing. This explains why the input variables in the relationship between media messages and election results are also correlated among themselves. In that case, the lack of independence between predictors is inherent in all data characterizing media influence, and researchers must deal with the collinearity problem.

Thus, in the case of media influence, one is not dealing with unidirectional causation, but with reciprocal causation in which media content plays a large role. The present analysis showed that people's election preferences were influenced by the frequency of valuations of political parties in the media. This means that valuations and constructions are offered through mass media messages with differing frequency and that some of them become thereby "chronically accessible" - they are activated in many different situations (Shrum 2002: 72). For the recipient, this continuously available information is the basis for constructing a reality sketch, and creating schemes about it, i.e., what the object currently under observation (political party, candidate, etc.) is in general and typically, and what one's attitude toward it should be. In making their judgments, people do not seek or use all of the available information, but only a small portion of it. Shrum (2002: 71) has called this the sufficiency principle.

On the whole, it may be concluded that the media exert a significant influence in forming voters' preferences. Media coverage that presents different events and gives valuations to political parties is the basis for the political decisions made by individuals and, in summary, forms the public's opinion in the election battle between competing political parties and politicians.

\section{References}

Brosius, H., and Kepplinger, H.M. (1992) Linear and Nonlinear Models of Agenda-Setting in Television. Journal of Broadcasting \& Electronic Media 36, 5-23.

Converse, P.E. (1970) Attitudes and Non-attitudes: Continuation of a Dialogue. - Tufte, E. R. (ed.) The Qualitative Analysis of Social Problems. Reading, Mass.: Addison-Wesley Publ. Co., 644-646.

Corner, J. (2000) 'Influence': The Contested Core of Media Research. - Curran, J. and Gurevitch, M. (eds.) Mass Media and Society. Third Edition. London: Arnold, 376-397.

Donsbach, W. (1996) Journalist. - Noelle-Neumann, E., Winfried Schulz, W. und Wilke, J. (Hrgb.) Publiziztik, Massenkommunikatsion. Frankfurt am Mein: Fischer Taschenbuch Verlag, 64-91.

Estonian National Electoral Committee. Elections to the local government councils 2002. Online. Available: http://www.vvk.ee/k02/e02index.html.

Estonian National Electoral Committee. Parliamentary Elections 2003. Online. Available: http:// www.vvk.ee/r03/e03index.html.

Estonian National Electoral Committee. Riigikogu valimine 1999. Online. Available: http://www.vvk.ee/ r03/tulemus/eesti_tulemus.html.

Fan, D.P. (1988) Predictions of Public Opinion From the Mass Media. Westport, CT: Greenwood.

Fan, D.P. (1996) Predictions of the Bush-Clinton-Perot Presidential Race From the Press. Political Analysis, 6 (1), 67-105.

Gerhards, J. (1991) Die Macht der Massenmedien und die Demokratie. Berlin: Wissenschaftszentrum Berlin für Sozialforschung, FS III, 91-108.

Iyengar, S., and Kinder, D. (1987) News That Matters. Chicago: University of Chicago Press.

JeYábek, H. (2001) Media Effects on Opinion Formation. Conference paper. - WAPOR Thematic Seminar “Survey Research and Media Content Analysis". Hamburg, Germany, June 21-23.

Judd, C.M. and Milburn, M.A. (1980) The Structure of Attitude Systems in the General Public: Comparisons of a Structural Equation Model, American Sociological Review, Vol. 45, 4, 627-643.

The author would like to thank Dr. Thomas Petersen at the Institut für Demoskopie Allensbach for his valuable advice. 
Katz, E., and Lazarsfeld, P.F. (1955) Personal Influence - The Part Played by People In the Flow of Mass Communication. Glencoe: The Free Press.

Katz, E., Blumer, J.G., Gurevich, M. (1974) The Uses and Gratifications Approach to Mass Communication. Beverly Hills: Sage.

Kinder, D. and Kiewiet, R. (1979) Economic Discontent and Political Behavior: The Role of Personal Grievances and Collective Economic Judgments in Congressional Voting. American Journal of Political Science 79, 10-27.

Kinder, D. and Kiewiet, R. (1981) Sociotropic Politics: The America Case. British Journal of Politics 11, 129-161.

Lewis-Beck, M. (1988) Economics and Elections: The Major Western Democracies. Ann Arbor, MI: The University of Michigan Press.

Luhmann, N. (1994) Soziale Systeme. Grundriß einer allgemeinen Theorie. Vierte Auflage. Frankfurt am Main: Suhrkamp.

Maletzke, G. (1963) Psychologie der Massenkommunikation. Theorie und Systematik. Hamburg: Verlag Hans-Bredow-Institut.

Maturana, H.R., and Varela, F.J. (1980) Autopoiesis and Cognition. The Realization of the Living. Dordrecht, Boston, London: D. Reidel Publishing Company.

McCombs, M., Sheldon, G. (1986) News Influence on Our Pictures of the World. - Bryant, J., Zillmann, D. (eds.) Perspectives on Media Effects 1. Hillsdale, New Jersey, London: Lawrence Erlbaum Associates.

McLeod, D.M., Kosicki, G. M. and McLeod, J.M. (2002) Resurveying the Boundaries of Political Communication Effects. - Briant, J. and Zillmann, D. (eds.) Media Effects. Advances in Theory and Research. Mahwah, New Jersey and London: Lawrence Erlbaum Associates, 215-267.

Merten, K. (1996) Chancen und Risiken der Informationsgesellschaft. - Tauss, J., Kollbeck, J. und Mönikes, J. (Hrgb.), Deutschlands Weg in die Informationsgesellschaft. Herausforderungen und Perspektiven für Wirtschaft, Wissenschaft, Recht und Politik. Baden-Baden, 82-95.

Merten, K. (1999) Einführung in die Kommunikationswissenschaft. Bd. 1/1: Grundlagen der Kommunikationswissenschaft. Münster: Lit.

Mosteller, F., and Tukey, J.W. (1977) Data Analysis and Regression. A Second Course In Statistics. Reading, Massachusetts: Addison-Wesley Publishing Company.

Mutz, D. (1998) Impersonal Influence: How Perceptions of Mass Collectives Affect Political Attitudes. Cambridge: Cambridge University Press.

Neuman, W.R. (1990) The Threshold of Public Attention. Public Opinion Quarterly 54, 159-176.

Norris, P., Curtice, J., Sanders, D., Scammell, M. and Semetko, H.A. (1999) On message: Communicating the Campaign. Thousand Oaks, New Dehli: SAGE Publications.

Pan, Z., and Kosicki, G.M. (1997) Priming and Media Impact on Evaluations of the President's Performance. Communication Research 24, 3-30.

Petersen, T. and Jandura, O. (2004) Der Test von Bildsignalen in Repräsentativumfragen und seine Verknüpfung mit Medieninhaltsanalysen im Bundestagswahlkampf 2002. - Knieper, T. and Müller, M. (Hrsg.).Visuelle Wahlkampfkommunikation. Köln: Herbert von Halem Verlag, 148-167.

Pinkleton, B.E. (1998) Effects of Print Comparative Political Advertising on Political Decision-Making and Participation. Journal of Communication 48, 24-36.

PM. (2003) Küsitlus lubab võitu Savisaarele [Poll Promises Victory to Savisaar]. Postimees, February 22, 2003.

Ruutsoo, R. (1998) Kodanikuühiskonna taasteke: senine areng ja perspektiivid. - Eesti inimarengu aruanne [The Reformation of the Citizen Society: It's Development Until Now and Perspectives. - The Estonian Development Report]. Tallinn, 38-41.

Salwen, M.B. (1988) Effect of Accumulation of Coverage on Issue Salience in Agenda-Setting. Journalism Quarterly 65, 100-106.

Schmitt-Beck, R., Pfetsch, B. (1994) Politische akteure und die Massenkommunikation. Zur Generierung von Öffentlichkeit in Wahlkämpfen. Kölner Zeitschrift für Soziologie und Sozialpsychologie, Sonderheft 34. Opladen: Westdeutscher Verlag, 106-138.

Shah, D.V., Watts, M.D., Domke, D., and Fan, D.P. (2002) News Framing and Cueing of Issue Regimes: Explaining Clinton's Public Approval in Spite of Scandal. Public Opinion Quarterly 66, 339-370.

Shrum, J.L. (2002) Media Consumption and Perceptions of Social Reality: Effects and Underlying Processes. - Briant, J. and Zillmann, D. (eds.) Media Effects. Advances in Theory and Research. Mahwah, New Jersey, London: Lawrence Erlbaum Associates, 69-95.

Sonner, B.S. (1998) The Effectiveness of Negative Political Advertising: A Case Study. Journal of Advertising Research 38, 37-42.

Stewart, D.W. (1989) Mesures, Methods, and Models of Advertising Response. Journal of Advertising Research 29, 54-60. 
Voog, A. (2003) Kodanike soov valimistel osaleda on viimastel nädalatel tõusnud. [The Desire of Citizens to Participate In Elections Has Increased In Recent Weeks]. Online. Available: http://www.emor.ee/ arhiiv.html?id.

Wanta, W. (1997) The Messenger and the Message: Differences Across News Media. - McCombs, M., Shaw, D. L. and Weaver, D. (eds.) Communication and Democracy. Exploring the Intellectual Frontiers in Agenda-Setting Theory. Mahwah: Lawrence Erlbaum Associates, 137-151.

Wanta, W., and Wei, H. (1993) The Agenda-setting Effects of International News Coverage: An Examination of Differing News Frames. International Journal of Public Opinion Research 5, 250-264.

Zhao, L., Chen, Y., and Schaffner, D.W. (2001) Comparison of Logistic Regression and Linear Regression in Modeling Presentage Data. Applied and Enviromental Microbiology 67, 2129-2135.

\section{Notes}

1. The idea of using, on the one hand, quantitative content analysis, which has been known since the beginning of the 20th century and, on the other hand, the opinion survey, which has been in use since the middle of the 19th century, was first advanced by Lazarsfeld, Berelson and Gaudet in 1940. The combination of these methods became more widely used in the late 1960s (see Petersen and Jandura 2004: 148-149). All of the results of studies done on influence are based on this combination of methods, regardless of which model or method of data processing was later used.

2. This new political party is not comprised of newcomers to politics, but to a large extent of individuals who had left the Pro Patria Union and the Reform Party.

3. In performing the content analysis, political advertising is usually coded as negative, comparative and positive. Negative advertising criticizes opponents and the sponsor of the advertising in the best instances is mentioned only in the tag line. In comparative ads, the opponent and the sponsor are both named. In positive advertising, the opponent is not named. Only positive advertising appeared in the observed publications prior to the parliamentary elections in 1999. In addition to the positive advertising prior to the 2003 parliamentary elections, there were three negative ads. Because three units is too small a number, only the number of positive ads was considered.

4. In order to calculate the parameters of regression models, percentages are widely used alongside the nominal values. Zhao et al. (2001: 2129) proved that "[g]enerally, the accuracy of linear models for modeling bounded variables (e.g., percentage data) is not as good as for other unbounded variables obtained in the same experiment." In the data presented in this article, this difference is extremely small. The coefficient of correlation is, of course, not affected by the form in which the data are presented, so either raw numbers or percentages are equally useful.

5. Due to collinearity, it is not possible to use other explanatory variables in the 1999 and 2002 models.

6. Because the number of political parties being observed was relatively small and because there are several explanatory variables, the coefficient of determination may show a deceptively significant relationship among the variables. For that reason, an adjusted coefficient of determination is used.

7. The 2003 parliamentary election campaign was unanimously evaluated by the Estonian press as being dirty and unethical. At the beginning of February 2003, the initial issues of the campaign - taxes, Estonia's entry into the European Union, the demographic situation, positions regarding the war in Iraq, etc. - had been put on the back burner, and the main theme of the election struggle became corruption. In reality, it became a war to compromise the opposing candidates, which resulted in the electorate turning its back on both the participating parties in the incumbent government coalition and the opposition parties, and placing its hopes in the newcomer Res Publica and the People's Union of Estonia (PUE), which during the year preceding the election did not belong to either the coalition or the opposition.

8. Here is an example of one of the peculiarities of post-communist journalism: Its universe is divided into "very good" and "very bad". Substantively, this highlights the fact that one of the most important criteria of objectivity - impartiality - does not exist. 